\title{
Süt Sığırcılığı İşletmelerinin Yapısal Özellikleri
}

\section{Araștırma Makalesi}

\author{
Bülent ÖZER ${ }^{1}$, Emine İKİKAT TÜMER ${ }^{1 *}$
}

\begin{abstract}
Öz
Bu çalışmada Mersin, Adana, Osmaniye ve Hatay illerinde süt sığırcılığı yapan işletmelerin yapısal özelliklerini, mevcut sorunlarını ortaya koymak ve bu sorunlara çözüm önerileri geliştirmek amaçlanmıştır. Bu amaçla araştırma bölgesinde 166 süt sığırı işletmecisi ile anket yapılmıştır. Elde edilen verilerin değerlendirilmesinde frekans, yüzde, ortalama ve standart sapma kullanılmıştır. Sonuç olarak; araştırma bölgesindeki işletmeler, ortalama 16.60 baş kültür ırkı inekten $16.38 \mathrm{~kg} / \mathrm{b}$ aş süt elde etmektedirler. Ayrıca işletmelerde yem bitkileri ve silajlık mısır yetiştiriciliği oranı da düşüktür. İşletmelerin en önemli sorunu ise kaba ve kesif yem fiyatlarının yüksek olması ve ürünlerini pazarlama imkanının kısıtlı olmasıdır.
\end{abstract}

Anahtar kelimeler: Süt, süt sığırcıllğı, Mersin, Adana, Osmaniye, Hatay

\section{ABSTRACT}

\section{Structural Features of Dairy Farming Enterprises}

In this study, it was aimed to identify the structural characteristics, existing problems of dairy cattle enterprises in Mersin, Adana, Osmaniye and Hatay provinces and to develop solutions to these problems. For this purpose, 166 dairy cattle farms were surveyed in the research area. Frequency, percentage, mean and standard deviation were used to evaluate the data obtained. As a result, farms in the research area receive an average of $272 \mathrm{~L} /$ day of milk from an average of 16.6 head of cows. In addition, the rate of growing forage crops and silage corn in farms is also low. The most important problem of farms is that forage and concentrate feed prices are high and marketing opportunities for their products are limited.

Keywords: Milk, dairy farms, Mersin, Adana, Osmaniye, Hatay

ORCID ID (Yazar sirasına göre)

0000-0002-5755-3269, 0000-0001-6336-3026

Yayın Kuruluna Geliş Tarihi: 01.04.2021

Kabul Tarihi: 01.12.2021

${ }^{1}$ Kahramanmaraş Sütçü İmam Üniversitesi Ziraat Fakültesi Tarım Ekonomisi Bölümü

*E-posta: etumer@ksu.edu.tr

Bu çalışma Bülent Özer'in doktora tezinden üretilmiştir. 


\section{Giriș}

Nüfus ve gelir artışının gıda tercihlerini etkilemesi hayvansal ürünlere olan talebi de artırmıştır. Dünya genelinde 6 milyardan fazla insanın süt ve süt ürünlerini tükettiği ve bu insanların önemli bir çoğunluğunun gelişmekte olan ülkelerde yaşadığı saptanmıştır. $\mathrm{Bu}$ ülkelerde üretim yapan ve gelirini artırmak isteyen çiftçiler süt ve süt ürünlerine olan talebin artmasıyla önemli bir firsat elde etmişlerdir (FAO, 2020). Dünyada yaklaşık 150 milyon hane, süt üreticiliği ile uğraşmaktadır. Dünya süt üretimi 1987 y1lında 522 milyon ton iken 2019 yılında 863 milyon tona yükselmiştir. Hindistan dünyanın en büyük süt üreticisidir ve dünya süt üretiminin \%20'sini karşılamaktadır. Süt üretiminde önemli payı bulunan diğer ülkeler ise sirasıyla Amerika Birleşik Devletleri, Pakistan ve Çin'dir. Türkiye'de toplam süt üretim miktarı 2019 yılında 23 milyon ton olarak hesaplanmıştır. Türkiye süt üretimi ile dünya sıralamasında 9. Sirada yer almaktadır (Anonim, 2021). Dünya süt üretiminin $\% 83$ 'ü sı̆̆ırlardan, \%14'ü mandalardan, \%2'si keçilerden, \%1'i koyunlardan ve $\% 0.3$ '̈̈ ise develerden sağlanmaktadır (FAO, 2020). Gelişmekte olan ülkelerde küçük tarım işletmelerinde süt üretimi yapılmakta ve ailelerin temel geçim kaynağını oluşturmaktadır (FAO, 2013). Türkiye'de süt sı̆̆ırcılığ1 faaliyeti küçük aile işletmelerinde yaygındır. Süt üretimi yapılan süt sığırı işletmeleri diğer ülkelere oranla Türkiye'de daha fazla olmasına rağmen işletme başına düşen hayvan sayısı azdır (ZMO, 2019). Süt üretimi insan sağlığı ve besin maddesi olmasının yanı sıra Türkiye'nin dış ticaretteki payının artırılması ülke ekonomisi açısından önemlidir (Turan ve ark., 2017). Süt üretiminde birim başına verimi en yüksek tür olması, farklı iklim ve koşullara uygunluğu, laktasyon süresinin uzun olması gibi başlıca nedenlerden dolayı süt sığırcılığı faaliyetini avantajlı kılmaktadır (Akman ve ark., 2013).

Türkiye şartlarında meralardan faydalanma oranının düşük olması, yem bitkileri üretiminin istenilen kalite ve düzeyde yapılmaması ekstansif ve entansif sığır yetiştiriciliğinin gelişmesine engel teşkil etmektedir. Türkiye yem bitkileri üretiminde önemli bir potansiyele sahip olup potansiyelin hayvansal üretimin sürdürülebilirliği açısından yem bitkileri üretiminin ve desteklerin artırılması gereklidir (Maç ve Yılmaz, 2016) Ayrıca küçük aile işletmelerinin büyüme eğiliminde olmaması, işletmelerde sığır sayısının az olması, pazarlama imkanlarının yetersiz olması ve çiftçilerin bilgi ve teknolojiden yeteri kadar faydalanmaması sığırcılığın başlıca sorunları arasindadir (Aksoy et al., 2011; Akman ve ark., 2013).

2019 yılı Hayvancılık Sektör Raporu'na göre; Türkiye'deki toplam 18 milyon baş sı̆̆ır varlığının \%48'ini kültür, \%43'ünü melez ve \%9'unu yerli rrk oluşturmaktadır (TİGEM, 2019).

(Ülkede son beş y1lda süt sığırcılığ1 faaliyetlerinde büyük ölçekli aile işletmelerinin sayısında artış olsa da küçük ölçekli aile işletmeleri daha yaygındır. Toplam süt sığırcılığı işletmelerinin büyük bir çoğunluğunda ortalama 10 başın altında hayvan bulunmaktadır. Küçük ve dağınık olan işletmeler, süt üretiminde ve sütün işleme tesislerine gönderilmesinde maliyeti artırmaktadır (TAGEM, 2019).

Üretici birliklerinin ve kooperatiflerin de katkısıyla Doğu Akdeniz Bölgesinde süt sığırcılı̆̆ı hızlı bir değişim ve gelişim göstermektedir. Adana ilinde yapılan çalışmalarda Şahin ve ark. (2001), entansif süt sığırcılı̆̆1 yapan işletmelerin üretim ekonomisini, Curabaz (2009), büyükbaş süt hayvancılığı ile uğraşan işletmeleri, Güğercin ve ark. (2017), bazı süt sığırcilı̆̆1 işletmelerindeki hayvan barınaklarının yapısını araştırmışlardır. Hatay ilinde ise Yılmaz ve ark. (2003), projeli ve projesiz süt sığırcılığı yapan işletmelerin üretim faaliyetlerini etkileyen faktörleri analiz etmeyi, Semerci ve ark. (2014), süt sığırcılı̆̆ işletmelerinin üretimini etkileyen faktörlerin analizini yapmayı, Semerci ve Çelik (2017), süt sı̆̆ırcılığı işletmelerinin sermaye yapısını araştırmayı amaçlamışlardır. Ata ve Yılmaz (2016), Süt hayvancılığ1 politikalarının Burdur ilinde modern ve geleneksel süt işletmelerinin sosyo-ekonomik ve teknolojik yapısını karşılaştırmışlardır. Ata ve Yılmaz (2015), Türkiye'de uygulanan hayvansal 
üretime yönelik destekleme politikalarının Burdur ilinde geliştirilmiş ve geleneksel süt sığırcıllğı faaliyetinde bulunan işletmeler üzerindeki ekonomik etkilerini araştırmışlardır. Ayrica Boz (2013) Doğu Akdeniz Bölgesinde (Kahramanmaraş, Hatay, Adana ve Osmaniye) süt sığırcılı̆̆ 1 faaliyeti yapan işletmelerin sorunlarını tespit ederek çözüm önerileri sunmuştur. Yılmaz ve ark. (2020), Doğu Akdeniz Bölgesi (Adana, Osmaniye, Mersin, Hatay, Kahramanmaraş) süt sığırcıllı̆̆ işletmelerinin sosyo-ekonomik yapısını ve süt sı ğırcılığ 1 faaliyet alanında yem kullanımının belirlenmesini amaçlamışlardır.

$\mathrm{Bu}$ çalışmada Mersin, Adana, Osmaniye, Hatay illerinde süt sığırcılığı yapan işletmelerin yapısal özelliklerini ortaya koymak ve mevcut sorunlara çözüm önerileri geliştirmek amaçlanmıştır.

\section{Materyal ve Yöntem}

Çalışmanın ana materyalini Mersin, Adana, Osmaniye, Hatay illerinde süt sığırcılığ faaliyeti ile uğraşan üreticilerle yüz yüze yapılan anketlerden elde edilen birincil veriler oluşturmaktadır. Anket uygulanacak işletmelerin sayısı Oransal Örnekleme yöntemiyle belirlenmiştir (Newbold, 1995).

$$
n=\frac{N * p^{*}(1-p)}{(N-1) * \sigma_{p}^{2}+p *(1-p)} \cong 166
$$

Formülde; n: Örnek büyüklüğü,

$\mathrm{N}$ : Popülasyondaki işletme sayısı (148066),

$\sigma_{\mathrm{p}}^{2}$ :Oranın varyans1,

p: Üretici sayısının popülasyondaki oranı (0.5),

r: Hata payı ve

$\mathrm{Z}$ : cetvel değerini göstermektedir.

$$
\sigma_{p}{ }^{2}=\left(\frac{r}{Z_{\alpha / 2}}\right)^{2}=\left(\frac{0.10}{2.576}\right)^{2}=0.0015
$$

Çalışmanın örnek hacmi \%99 güven aralığı ve $\% 10$ örnekleme hatası ile 166 olarak hesaplanmıştır. Araştırmanın ana kitlesini 2018 yılı Mart-Mayıs ayları arasında Mersin, Adana, Osmaniye, Hatay illerinde süt sığırcıllğı alanında faaliyet gösteren işletmeler oluşturmuşstur. Anketlerden elde edilen verilerin frekans, yüzde, ortalama ve standart sapmaları hesaplanmış ve tablolar halinde sunulmuştur. Süt sığırcılığı ile ilgili üreticilerin sorunlarının belirlenmesinde beşli Likert ölçeği (1: Kesinlikle Katılmıyorum, 2: Katılmıyorum, 3: Orta Düzeyde Kat1lıyorum, 4: Katıl1yorum, 5: Kesinlikle Kat1liyorum) kullanılarak elde edilen sonuçlar ortalama ve standart sapma yardımıyla yorumlanmıştır.

\section{Araştırma Bulguları}

Araştırma yapılan işletmelerde ankete katılan üreticilerin ortalama yaşı 40.45 y1l ve ortalama süt sı ğırc1lığ1 tecrübeleri 18.97 y1l olarak hesaplanmıştır. Ankete katılanların \%54.2'si lise mezunudur. İşletmelerdeki aile birey sayısı ortalamas1 3.60 kişi olup bunların 3.01'i süt sığırcılığı ile uğraşmaktadır. Üreticilerin \%32.5'inin $26 \quad 000$ TL'den daha az, $\% 36.7$ 'sinin 26000 ve $49000 \mathrm{TL}$ aralığında, $\% 30.7$ 'sinin ise $50000 \mathrm{TL}$ ve üzeri yıllık gelire sahip olduğu tespit edilmiştir. İşletmecilerin \%81.3'ünün asıl gelir kaynağı hayvansal üretim olup \%85.5'inin işletme dış1 yatırımı bulunmamaktadır. Üreticilerin \%63.9'u son beş yılda tarımsal üretime yatırım yapmıştır (Çizelge 1). Doğu Akdeniz Bölgesinde süt sığırı üreticilerinin ortalama yaşı 44.58 yıl olarak hesaplanmıştır. Çalışmaya katılanların \%61.0'i ilkokul mezunu ve \%36.0'1 tarımsal üretime son üç yılda yatırım yapmıştır (Boz, 2013). Diyarbakır ilinde işletmelerin \%90'ının aile işletmesi ve işletme sahiplerinin \%43'ünün ilkokul mezunu olduğu tespit edilmiştir (Tutkun ve ark., 2017) Burdur ilinde geliştirilmiş süt hayvancıllğ̣ işletmelerinde üreticilerin yaş ortalamas1 41.88 olup 15.84 y1l tecrübeye sahiptirler. Geleneksel işletmelerde üreticilerin yaş ortalamas1 42.78, tecrübe süreleri 15.02 y1ldır (Ata ve Y1lmaz, 2016). Doğu Akdeniz Bölgesinde aile birey sayısı ortalama 4.84 kişi, süt sığırcılığı deneyim yılı ortalama 16.24, ilkokul ve üzeri eğitim alanlarını oranı ise \%35.05'tir (Y1lmaz ve ark., 2020). 
Çizelge 1. Üreticilerin sosyo-demografik özellikleri

\begin{tabular}{|c|c|c|c|}
\hline \multicolumn{2}{|l|}{ Değişkenler } & Üretici say1s1 & $\%$ \\
\hline \multirow{4}{*}{$\begin{array}{l}\text { Yaş (y1l) } \\
\text { (ort: } 40.45 \text { yıl) }\end{array}$} & $<31$ & 43 & 25.9 \\
\hline & $31-44$ & 63 & 38.0 \\
\hline & 45 ve üzeri & 60 & 36.1 \\
\hline & Toplam & 166 & 100.0 \\
\hline \multirow{4}{*}{$\begin{array}{l}\text { Süt sığırcılığı tecrübesi } \\
(18.97 \mathrm{y} 1)\end{array}$} & $1-10$ y1l & 47 & 28.3 \\
\hline & $11-20$ y1l & 82 & 49.4 \\
\hline & $>20$ y1l & 37 & 22.3 \\
\hline & Toplam & 166 & 100.0 \\
\hline \multirow{6}{*}{ Eğitim } & Okuryazar & 4 & 2.4 \\
\hline & İlkokul & 30 & 18.1 \\
\hline & Ortaokul & 32 & 19.3 \\
\hline & Lise & 90 & 54.2 \\
\hline & Üniversite & 10 & 6.0 \\
\hline & Toplam & 166 & 100.0 \\
\hline \multirow{3}{*}{$\begin{array}{l}\text { Ailedeki birey sayıs1 } \\
\text { (ort: 3.60) }\end{array}$} & $\leq 3$ & 83 & 50.0 \\
\hline & $\geq 4$ & 83 & 50.0 \\
\hline & Toplam & 166 & 100.0 \\
\hline \multirow{3}{*}{$\begin{array}{l}\text { Ailede tarımla uğraşan birey } \\
\text { sayıs1 (ort: } 3.14 \text { ) }\end{array}$} & $<3$ kişi & 53 & 31.9 \\
\hline & $3+$ kişi & 113 & 68.1 \\
\hline & Toplam & 166 & 100.0 \\
\hline \multirow{3}{*}{$\begin{array}{l}\text { Ailede süt sığırcıllğıyla uğraşan } \\
\text { birey sayısı (ort: } 3.01 \text { ) }\end{array}$} & $<3$ kişi & 57 & 34.3 \\
\hline & $3+$ & 109 & 65.7 \\
\hline & Toplam & 166 & 100.0 \\
\hline \multirow{4}{*}{$\begin{array}{l}\text { Gelir (TL/y1l) } \\
\text { (ort:48.903 TL/y11) }\end{array}$} & $<26000$ & 54 & 32.5 \\
\hline & $\begin{array}{l}26000- \\
49000\end{array}$ & 61 & 36.7 \\
\hline & $50000+$ & 51 & 30.7 \\
\hline & Toplam & 166 & 100.0 \\
\hline \multirow{3}{*}{ İşletmecinin as1l gelir kaynağ } & $\begin{array}{l}\text { Karma } \\
\text { üretim }\end{array}$ & 31 & 18.7 \\
\hline & $\begin{array}{l}\text { Hayvansal } \\
\text { üretim }\end{array}$ & 135 & 81.3 \\
\hline & Toplam & 166 & 100.0 \\
\hline \multirow{3}{*}{ Tarımsal işletme dışı yatırım } & Hayır & 142 & 85.5 \\
\hline & Evet & 24 & 14.5 \\
\hline & Toplam & 166 & 100.0 \\
\hline \multirow{3}{*}{$\begin{array}{l}\text { Son beş yılda tarımsal } \\
\text { yatırım yapma durumu }\end{array}$} & Hayır & 106 & 63.9 \\
\hline & Evet & 60 & 36.1 \\
\hline & Toplam & 166 & 100.0 \\
\hline
\end{tabular}

Araştırma bölgesindeki işletmelerde ortalama hayvan varlığı; 16.6 baș inek, 6.21 baș buzağı, 3.53 baş dana, 2.82 baş düve, 2.41 baş boğa/tosun olarak saptanmıştır (Çizelge 2). Erzurum ili Pasinler ilçesinde işletmelerdeki ortalama hayvan varlığ 13.22 baş inek, 4.37 baş düve, 3.78 baş dana, 2.71 baş buzağı ve
4.14 baş boğa/tosun (Sayar, 2018), Çanakkale İli Biga İlçesinde Süt Üreticilerinin işletmelerinde Ortalama 8.6 baş inek, 1.4 dana, 3.2 düve, 2.98 buzağı (Büyükcan ve Tan, 2020), Afyonkarahisar ilinde süt sı ğırcılığı işletmelerinde ortalama 79.64 baş inek, 30.00 düve, 34.18 buzağı/dana (Karakuş, 2021) 
olduğu tespit edilmiştir.

Çizelge 2. İşletmelerin hayvan varlığı (baş)

\begin{tabular}{|c|c|c|c|}
\hline \multicolumn{2}{|l|}{ Hayvan Cinsi } & Ortalama & Toplam (baş) \\
\hline İnek & $\begin{array}{l}\text { Yerli } \\
\text { Melez } \\
\text { Kültür }\end{array}$ & $\begin{array}{r}0.95 \\
0.37 \\
15.28\end{array}$ & 16.60 \\
\hline Boğa/Tosun & $\begin{array}{l}\text { Yerli } \\
\text { Melez } \\
\text { Kültür } \\
\end{array}$ & $\begin{array}{l}0.09 \\
0.21 \\
2.11 \\
\end{array}$ & 2.41 \\
\hline Düve & $\begin{array}{l}\text { Yerli } \\
\text { Melez } \\
\text { Kültür }\end{array}$ & $\begin{array}{l}0.08 \\
0.07 \\
2.67\end{array}$ & 2.82 \\
\hline Dana & $\begin{array}{l}\text { Yerli } \\
\text { Melez } \\
\text { Kültür } \\
\end{array}$ & $\begin{array}{l}0.24 \\
0.20 \\
3.09 \\
\end{array}$ & 3.53 \\
\hline Buzağı & $\begin{array}{l}\text { Yerli } \\
\text { Melez } \\
\text { Kültür }\end{array}$ & $\begin{array}{l}0.49 \\
0.82 \\
4.90 \\
\end{array}$ & 6.21 \\
\hline
\end{tabular}

Tarımda makineleșme (tarımsal mekanizasyon) sayesinde işletmeler daha hızlı ve geniş kapasitede üretim yapabilmektedir. Böylece işletmelerin teknik ve ekonomik etkinliği artırılarak üretim performansı iyileştirilmektedir (Saral ve ark., 2000). Mevcut üretimden sağlanacak verimin tespit edilmesi veya verim artışının sağlanması bakımından işletmelerin Çizelge ). tarımsal alet ve makine varlığının bilinmesi önem taşımaktadır.Elde edilen verilere göre işletmelerin \%97.6'sında süt sağım makinesi, \%94.6'sinda traktör, \%84.9'unda römork, 79.5 'inde süt güğümü, $\% 41.0$ 'ında suluk, $\% 25.9$ 'unda süt tank1 ve \%22.9'unda ise yem karma makinesi bulunmaktadır (

Çizelge 3. İşletmelerin alet-makine varlığı

\begin{tabular}{|l|c|c|}
\hline Alet-makine & İşletme sayıs1 & $\%$ \\
\hline Süt Sağım Makinesi & 162 & 97.6 \\
\hline Traktör & 157 & 94.6 \\
\hline Römork & 141 & 84.9 \\
\hline Süt Güğ̈mü & 132 & 79.5 \\
\hline Suluk & 68 & 41.0 \\
\hline Süt Tank1 & 43 & 25.9 \\
\hline Yem Karma Makinesi & 38 & 22.9 \\
\hline
\end{tabular}

Süt ineklerinin temel besin öğelerini karşılayabilmek için kaba ve kesif yem tercih edilmektedir. Kaba yemler, içerik bakımından zengin yemlerdir ve hayvan sağlığ 1 ve sindirim sisteminin sorunsuz bir şekilde çalışması açısından önemlidir. Kesif yemler, doğasında besin maddesi ve düşük selüloz oranı içerdiğinden hem süt hayvanı hem de besi hayvanının beslenmesinde kaba yemle beraber verilmektedir (Gülsün ve Miç, 2018).

Mersin, Adana, Osmaniye, Hatay illerindeki üreticilerin \%22.9'unun hayvanların verim düzeylerine göre farklı rasyon uygulaması yaptığ 1 ve \%58.4'ünün yem rasyonu hazırlarken kaba ve kesif yem oranına dikkat ettiği saptanmıștır. Üreticilerin \%30.7'si kaba yem üretmekte, \%25.3'ü yem bitkisi yetiștirmekte, \%6.0's1 misir silaji yapmakta ve \%33.7'si misir 
silaj1 yapmak istemektedir. Üreticilerin \%70.5'inin buzağ 1 başlangıç ve büyütme yemi, $\% 55.4$ 'ü yataklık kullanmaktadır. Süt sığırı yetiştiricilerinin \%58.4'ünün hazırlanan yemin ham protein oranına, \%60.8'inin ise metabolik enerji miktarına dikkat ettiği tespit edilmiştir. Araştırma kapsamında üreticilerin \%97.6’sının suni tohumlama, \%72.3'ünün tabii tohumlama yaptırdığı tespit edilmiştir. Üreticilerin \%20.5'inin hayvanlarında k1sırlık olduğu tespit edilmiştir. Ayrıca işletme sahiplerinin sadece \%3.6'sı sertifikalı çoban bulabilmektedirler (Çizelge 4).

Gençdal ve ark. (2015), Van ili Gevaş ilçesinde süt sığırcılığ̀ işletmelerinde üreticilerin $\% 56.8$ 'inin suni tohumlama yaptırdığını \%43.2' sinin ise yaptırmadığını saptamışlardır.

Çizelge 4. İşletmede rasyon uygulamasına ilişkin bilgiler

\begin{tabular}{|l|r|r|c|}
\hline & \multicolumn{1}{|c|}{ Hayır } & \multicolumn{1}{c|}{ Evet } & Toplam \\
\hline $\begin{array}{l}\text { İşletmede hayvanların verim düzeylerine göre gruplama } \\
\text { (farklı rasyon uygulaması) yapma durumu }\end{array}$ & 77.1 & 22.9 & 100.0 \\
\hline $\begin{array}{l}\text { Hazırlanan yem rasyonunda kaba ve kesif yem oranına } \\
\text { dikkat etme durumu }\end{array}$ & 41.6 & 58.4 & 100.0 \\
\hline Kaba yem üretme durumu & 69.3 & 30.7 & 100.0 \\
\hline Yem bitkisi yetiştirme durumu & 74.7 & 25.3 & 100.0 \\
\hline Mısır silajı yapma durumu & 94.0 & 6.0 & 100.0 \\
\hline Misır silajı yapma isteği & 66.3 & 33.7 & 100.0 \\
\hline Mısır silajı konusunda eğitim alma durumu & 95.8 & 4.2 & 100.0 \\
\hline Buzağ1 başlangıç ve büyütme yemi kullanma durumu & 29.5 & 70.5 & 100.0 \\
\hline Yataklık kullanma durumu & 44.6 & 55.4 & 100.0 \\
\hline Hazırlanan yemin ham protein oranına dikkat etme & 41.6 & 58.4 & 100.0 \\
\hline Hazırlanan yemin metabolik enerji miktarına dikkat etme & 39.2 & 60.8 & 100.0 \\
\hline Suni tohumlama yaptırma durumu & 2.4 & 97.6 & 100.0 \\
\hline Tabii tohumlama yaptırma durumu & 27.1 & 72.3 & 100.0 \\
\hline Hayvanların döl tutmama (kısır kalma) durumu & 79.5 & 20.5 & 100.0 \\
\hline Yapılan suni tohumlamadan memnun olma durumu & 4.2 & 95.8 & 100.0 \\
\hline Sertifikalı çoban bulma durumu & 96.4 & 3.6 & 100.0 \\
\hline
\end{tabular}

Üreticilerin \%37.3’ünün ahır gübresini arazisine attığı tespit edilmiştir (Boz, 2013). isteyenlere vererek, \%30.1'inin satarak, Burdur ilinde süt sı̆̆ırcılı̆̆1 işletmelerinde elde \%18.7'sinin kendi arazisine ve \%13.9'unun edilen ahır gübresinin \%89.27'sinin işletmede meraya atarak değerlendirdiği saptanmıştır kullanıldığı belirlenmiştir (Özyakar ve Yılmaz, (Çizelge 5). Doğu Akdeniz Bölgesinde 2021). üreticilerin \%62.5'inin ahır gübresini kendi

Çizelge 5. Ahır gübresinin değerlendirilmesi

\begin{tabular}{|l|l|c|c|}
\hline \multicolumn{2}{|l|}{ Değişkenler } & Üretici sayıs1 & $\%$ \\
\hline \multirow{4}{*}{$\begin{array}{l}\text { Ahır gübresini } \\
\text { değerlendirme }\end{array}$} & Kendi arazime atıorum & 31 & 18.7 \\
\cline { 2 - 4 } & Seraya at1yorum & 23 & 13.9 \\
\cline { 2 - 4 } & İstyorum & 50 & 30.1 \\
\cline { 2 - 4 } & Toplam & 62 & 37.3 \\
\hline
\end{tabular}

Sığırcılık işletmelerinde uygun bakım ve düşecektir (Şeker ve ark., 2012). Mastitis; süt idarenin yanı sıra hayvan sağlığı ve veteriner sı̆̆ırcılığında yaygın olarak karşılaşılan, hekimlik hizmetleri de önemli giderler memenin körleşerek süt verimini azaltan ve son arasındadır. Hastalıkların görüldüğü, sağlık ve derece dikkat edilmesi gereken bir meme veteriner hizmetlerinin yetersiz kaldığ durumlarda üreticilerin verim ve gelirleri kasaplık hayvan olarak kullanılmaktadır. Bazı 
durumlarda, bu hastalığın hayvan ölümlerine yol açtığı saptanmıştır (Gürgen, 2005).

Araştırma Bölgesinde üreticilerin \%89.8'inin hayvanlarında meme hastalığının görüldüğü ve bu hastalıkların en fazla \%58.4 oranı ile Mastitis olduğu saptanmıştır. Üreticilerin \%66.9'unun düzenli olarak veteriner hizmetlerinden destek aldığ tespit edilmiştir.
İşletmelerin \%55.4'ünde Şap， \%18.1'inde Brucella, \%13.9'unda Şarbon, \%12.6'sinda ise diğer aşıları (Tuberculosis, Yanıkara) düzenli olarak yaptırdığ1 tespit edilmiştir (Çizelge 6). Bakır (2002), Van ilinde yaptığı çalışmada bölgedeki işletmelerde en fazla şap hastalığ (\%67.5) olduğunu tespit etmiştir.

Çizelge 6. İşletme sağlik ve veteriner bilgileri

\begin{tabular}{|c|c|c|c|}
\hline & & Üretici sayıs1 & $\%$ \\
\hline \multirow{5}{*}{$\begin{array}{l}\text { En fazla karşılaşılan meme } \\
\text { hastalığ } 1 \text { çeşitleri }\end{array}$} & Mastitis & 97 & 58.4 \\
\hline & Süt bozukluğu & 34 & 20.5 \\
\hline & Yara & 18 & 10.8 \\
\hline & K1zarıklık & 17 & 10.2 \\
\hline & Toplam & 166 & 100.0 \\
\hline \multirow{3}{*}{$\begin{array}{l}\text { Düzenli olarak veteriner } \\
\text { hekimden destek alma }\end{array}$} & Hayır & 55 & 33.1 \\
\hline & Evet & 111 & 66.9 \\
\hline & Toplam & 166 & 100.0 \\
\hline \multirow{6}{*}{ En fazla yaptırılan aşı türü } & Șap & 92 & 55.4 \\
\hline & Brucella & 30 & 18.1 \\
\hline & Şarbon & 23 & 13.9 \\
\hline & Tuberculosis & 17 & 10.2 \\
\hline & Yanıkara & 4 & 2.4 \\
\hline & Toplam & 166 & 100.0 \\
\hline
\end{tabular}

İşletmelerin sürdürülebilir başarıya ulaşabilmesi için kayıt tutulması büyük önem taşımaktadır. Araştırma bölgesindeki üreticilerin \% $\%$ 8.3'ünün tohumlama, \%76.5'inin doğum, \%67.5'inin sağlık, \%91.0'ının günlük süt üretimi ve \%68.7'sinin yemleme kayıtlarını tuttuğu saptanmıştır. Üreticilerin \%97.6'sının hayvan ağırlıklarıyla ilgili, \%83.7'sinin ise sürüden çıkarılan hayvanlar için kayıt defteri tutmadığı tespit edilmiştir (Çizelge 7). Araştırma bölgesinde ankete katılanların büyük çoğunluğu, hayvan ağırlıkları ve sürüden çıkarılan hayvanlar ile ilgili düzenli kayıt tutma dışında tüm bilgileri kayıt altına alma eğilimindedirler.

Boz 2013 yılındaki çalışmasında, işletmelerin $\% 88.8$ 'inde tohumlama, \%67.5'inde doğum, $\% 31.9$ 'unda sağlı, $\% 40.0$ 'ında süt üretim, $\% 13.8$ 'inde hayvan ağırlık, \%23.1'inde sürüden çıkarılan hayvan ve \%18.1'inde yemleme ile ilgili kayıt tutulduğunu tespit etmiştir.

Çizelge 7. Kayıt bilgileri (\%)

\begin{tabular}{|l|c|c|c|}
\hline & Hayır & Evet & Toplam \\
\hline Tohumlama defteri tutma durumu & 21.7 & 78.3 & 100.0 \\
\hline Doğum defteri tutma durumu & 23.5 & 76.5 & 100.0 \\
\hline $\begin{array}{l}\text { Sağlık (aşılama ve hastalıkla ilgili) kaydı tutma } \\
\text { durumu }\end{array}$ & 32.5 & 67.5 & 100.0 \\
\hline Günlük süt üretim kaydı tutma durumu & 9.0 & 91.0 & 100.0 \\
\hline Yemleme kaydı tutma durumu & 31.3 & 68.7 & 100.0 \\
\hline Hayvan ağırlıklarılyla ilgili kayıt tutma durumu & 97.6 & 2.4 & 100.0 \\
\hline $\begin{array}{l}\text { Sürüden çıarılan hayvanlara ait kayıt tutma } \\
\text { durumu }\end{array}$ & 83.7 & 16.3 & 100.0 \\
\hline
\end{tabular}


Süt sığırc1lı̆̆ 1 faaliyeti yapan üreticilerin \%95.8'i sağımdan önce meme temizliği yaptığını ve \%75.3'ü sağımda meme daldırma solüsyonu kullandığını belirtmiştir (Çizelge 8).

Sütün dondurulmadan soğumasını sağlayan süt soğutma tanklarının bir diğer görevi ise sütü zararlı bakterilerden korumaktır (Günhan ve ark., 2006).

Üreticilerin \%75.9'unun sütü güğüm içine, \%14.5'inin ise süt soğutma tankına sağdığ saptanmıştır. Sütü galvanize gügümlerde muhafaza eden üreticilerin oranı \%82.5 olarak, soğutmalı tanklarda muhafaza eden üreticilerin oranı ise \%15.1 olarak hesaplanmıştır. Birliğe gönderilen süt ölçümlerini tahmini olarak belirleyen üreticilerin oranı $\% 39.8$, otomatik ölçer ile ölçüm yapanların oranı \%22.9, birliğe süt göndermeyenlerin oranı ise $\% 31.3$ olarak tespit edilmiştir (Çizelge 8).

Çizelge 8. Sağım ve süt bilgileri

\begin{tabular}{|c|c|c|c|}
\hline & & Üretici say1s1 & $\%$ \\
\hline \multirow{3}{*}{$\begin{array}{l}\text { Sağımdan önce meme temizliği } \\
\text { yapma durumu }\end{array}$} & Hayır & 7 & 4.2 \\
\hline & Evet & 159 & 95.8 \\
\hline & Toplam & 166 & 100.0 \\
\hline \multirow{3}{*}{$\begin{array}{l}\text { Sağımda meme daldırma } \\
\text { solüsyonu kullanma durumu }\end{array}$} & Hayır & 41 & 24.7 \\
\hline & Evet & 125 & 75.3 \\
\hline & Toplam & 166 & 100.0 \\
\hline \multirow{4}{*}{ Süt sağılan kaplar } & Güğüm & 126 & 75.9 \\
\hline & Süt soğutma tank1 & 24 & 14.5 \\
\hline & Kova-Bidon & 16 & 9.6 \\
\hline & Toplam & 166 & 100.0 \\
\hline \multirow{4}{*}{$\begin{array}{l}\text { Sağılan sütün muhafaza edilme } \\
\text { şekli }\end{array}$} & $\begin{array}{l}\text { Galvanize } \\
\text { güğümlerde }\end{array}$ & 137 & 82.5 \\
\hline & Soğutmalı tanklarda & 25 & 15.1 \\
\hline & Diğer & 4 & 2.4 \\
\hline & Toplam & 166 & 100.0 \\
\hline \multirow{5}{*}{$\begin{array}{l}\text { Birliğe gönderilen sütün ölçüm } \\
\text { işlemi }\end{array}$} & Tahmini ölçerek & 66 & 39.8 \\
\hline & Kova ile ölçerek & 10 & 6.0 \\
\hline & Otomatik ölçer ile & 38 & 22.9 \\
\hline & $\begin{array}{l}\text { Birliğe süt } \\
\text { göndermiyorum }\end{array}$ & 52 & 31.3 \\
\hline & Toplam & 166 & 100.0 \\
\hline
\end{tabular}

İncelenen işletmelerde üretimi yapılan ortalama süt miktarı $272.0 \mathrm{~kg}$, satılan süt miktarı 201.0 $\mathrm{kg}$, inek başına süt verimi $16.38 \mathrm{~kg} / \mathrm{b}$ aş olarak saptanmıştır. Üretimi yapılan peynir miktarı $37.8 \mathrm{~kg}$ ve satılan peynir miktarının $29.5 \mathrm{~kg}$ olduğu tespit edilmiştir. Ayrıca ortalama tereyağ1 üretim miktarı $15.0 \mathrm{~kg}$ ve satılan tereyağı miktarının $10.5 \mathrm{~kg}$ olduğu sonucuna ulaşılmıştır.
İncelenen işletmelerde elde edilen hayvansal ürünlerin ortalama satış fiyatlarının süt için 1.84 TL, peynir için $17.80 \mathrm{TL}$ ve tereyağı için ise 33.50 TL olduğu sonucuna ulaşılmıştır (Çizelge 9). Burdur ilinde günlük süt üretimi ortalama 397.75 (kg/süt) olup süt verimi 22.99 (kg/baş) olarak tespit edilmiştir (Dönmez, 2019). 
Çizelge 9. Ekonomik faaliyet türlerine göre elde edilen hayvansal ürünler

\begin{tabular}{|l|c|c|}
\hline Ürünler/Ortalama Fiyat1 & Üretim/Satış/Tüketim & $\begin{array}{c}\text { Ortalama } \\
(\mathrm{Lt} / \mathrm{Kg})\end{array}$ \\
\hline & Üretilen & 272.0 \\
Süt & Satılan & 201.0 \\
$(1.84 \mathrm{TL} / \mathrm{lt})$ & Ev tüketilen & 71.0 \\
\hline & Üretilen & 37.8 \\
Peynir & Satılan & 29.5 \\
$(17.80 \mathrm{TL} / \mathrm{Kg})$ & Ev tüketilen & 8.3 \\
\hline & Üretilen & 15.0 \\
Tereyağ1 & Satılan & 10.5 \\
$(33.50 \mathrm{TL} / \mathrm{Kg})$ & Ev tüketilen & 4.50 \\
\hline
\end{tabular}

Üreticiler; ürettikleri sütün \%41.6'sın1, peynirin tutulmadan çiğ süt olarak tüketiciye ulaştığ1, $\% 27.7$ 'sini ve tereyağının \%26.5'ini firmalara \%50'sinin mandıralara gönderildiği ve satmaktadır (Çizelge 10). Çukurova bölgesinde \%10'unun ise fabrikalarda değerlendirildiği üretilen sütün \%40’ının herhangi bir işleme tabi tespit edilmiştir (Gönç ve ark., 1993).

Çizelge 10. Elde edilen hayvansal ürünlerin satıldığı yer ve dağılımları

\begin{tabular}{|c|c|c|c|}
\hline & & Üretici sayıs1 & $\%$ \\
\hline \multirow{6}{*}{ Süt satış1 yapılan yer } & Firma & 69 & 41.6 \\
\hline & Kooperatif & 30 & 18.1 \\
\hline & Semt-pazar satış1 & 27 & 16.3 \\
\hline & Mandira & 25 & 15.0 \\
\hline & Toplayıc1 & 15 & 9.0 \\
\hline & Toplam & 166 & 100.0 \\
\hline \multirow{6}{*}{ Peynir satış1 yapılan yer } & Firma & 46 & 27.7 \\
\hline & Kooperatif & 45 & 27.1 \\
\hline & Semt-pazar satışı & 34 & 20.5 \\
\hline & Mandira & 22 & 13.3 \\
\hline & Toplayıc1 & 19 & 11.4 \\
\hline & Toplam & 166 & 100.0 \\
\hline \multirow{6}{*}{$\begin{array}{l}\text { Tereyağı satışı yapılan } \\
\text { yer }\end{array}$} & Firma & 44 & 26.5 \\
\hline & Kooperatif & 40 & 24.1 \\
\hline & Semt-pazar satıș1 & 30 & 18.1 \\
\hline & Mandira & 27 & 16.3 \\
\hline & Toplayıc1 & 25 & 15.0 \\
\hline & Toplam & 166 & 100.0 \\
\hline
\end{tabular}

Araştırma bölgesinde süt sığırcılığında üreticilerin karşılaştıkları sorunlar beșli Likert ölçeğinde sorulmuş ve elde edilen veriler ortalamalarına göre sıralanmıştır. Üreticilerin en fazla sorun yaşadığı konuların 'kaba ve kesif yem fiyatlarının yüksek olması' (4.90), 'yeterli mera alanının olmaması' (4.77), 'süt üretimine yönelik politikaların'(4.73) ve 'yem bitkilerinin' (4.70) yetersizliğinden kaynaklı olduğu saptanmıştır.
Üreticilerin 'sütü pazarlayamıorum' (4.39), 'kurumsal işletmelerle rekabet edemiyorum' (4.33), 'teknik bilgim yetersiz' (3.70), 'eğitim faaliyetleri' (3.66) ve 'hayvancilik desteklemeleri yetersiz' (3.57) önermelerine katıldıkları saptanmıştır. 
Bunun yanı sira üreticiler 'hayvanlar sik s1k hastalaniyor' (2.33), 'kaliteli boğa bulamiyorum' (2.16) ve 'süt üretiminde hijyenik koşulları sağlayamıyorum’ (2.13) yargılarına katılmadıkları tespit edilmiştir
(Çizelge 11). Bölgede en önemli sorunun yem fiyatlarının yüksek, buna karşın ürün fiyatlarının düşük olduğu tespit edilmiştir.

Çizelge 11. İşletmecilerin süt sığırcılığ 1 konusundaki sorunları

\begin{tabular}{|c|c|c|}
\hline Sorunlar & Ortalama* & Std. sapma \\
\hline Kaba ve kesif yem fiyatları yüksek & 4.90 & 0.406 \\
\hline Yeterli mera alanı bulamıyorum & 4.77 & 0.721 \\
\hline Süt üretiminde yönelik politikalar yetersiz & 4.73 & 0.530 \\
\hline Yem bitkilerinin yetersizliği & 4.70 & 0.656 \\
\hline Sütü pazarlayamıyorum & 4.39 & 1.200 \\
\hline Hayvan besleme konusunda teknik bilgim yetersiz & 4.36 & 1.096 \\
\hline Kurumsal işletmelerle rekabet edemiyorum & 4.33 & 0.605 \\
\hline Kaliteli kaba yem bulamıyorum & 4.32 & 1.330 \\
\hline Düșük süt verimi & 4.28 & 0.984 \\
\hline Sermayem yetersiz & 4.25 & 0.851 \\
\hline Hayvan ithalatı üretimi ve fiyatları olumsuz etkiliyor & 4.22 & 0.766 \\
\hline Canlı hayvan pazarlama & 4.11 & 1.098 \\
\hline Buzağ1 yetiştirme durumu & 3.98 & 3.107 \\
\hline Teknik bilgim yetersiz & 3.70 & 3.327 \\
\hline Yetersiz eğitim faaliyetleri & 3.66 & 0.971 \\
\hline Hayvancılık destekleri & 3.57 & 0.987 \\
\hline İşletmede çalışacak yeterli aile işgücü yok & 3.37 & 0.943 \\
\hline Uygun inek 1rk1 seçimi & 3.18 & 0.936 \\
\hline Suni tohumlamanın başarısız olması & 3.16 & 1.175 \\
\hline Uygun damızlık seçimi & 3.16 & 0.947 \\
\hline Gebelik ve doğum & 3.16 & 1.059 \\
\hline Ahır hayvancılığa elverişli değil & 3.13 & 0.788 \\
\hline Kalifiye işgücü bulamıyorum & 3.10 & 1.214 \\
\hline Verimi yüksek inek bulamıyorum (satılmıyor) & 3.02 & 1.141 \\
\hline Çoban bulamiyorum & 3.02 & 0.953 \\
\hline Ahırın yeterli kapasitesi yok & 2.98 & 0.901 \\
\hline Bakanlığın veteriner hizmetleri yetersiz & 2.93 & 1.217 \\
\hline Ot ve saman yapma döneminde yağışlar fazla & 2.88 & 0.745 \\
\hline Hastalıklarla mücadele & 2.87 & 0.825 \\
\hline Desteklerden haberdar olamiyorum & 2.73 & 1.134 \\
\hline Üreticiler birliği veya kooperatif üyeliği & 2.70 & 1.232 \\
\hline Hayvan hayat sigortası yaptırma & 2.68 & 4.150 \\
\hline İneğin kızgınlık gösterdiğini zamanında tespit edemiyorum & 2.66 & 0.989 \\
\hline Ahır hijyeni & 2.40 & 0.778 \\
\hline Hayvanlar sik hastalanıyor & 2.33 & 0.827 \\
\hline Kaliteli boğa bulamıyorum & 2.16 & 1.079 \\
\hline Süt üretiminde hijyenik koșulları sağlayamıyorum & 2.13 & 1.000 \\
\hline
\end{tabular}

*1: Kesinlikle katılmıyorum, 5: Kesinlikle katılıyorum 
Y1lmaz ve Ata (2016) Burdur ilinde geliştirilmiş süt sığırcılığ işletmelerinde yem bitkisi üretiminin olmamas1 (\%24.0), yetersiz ve uygun olmayan ahır (\%12.0), işgücü eksikliği (\%16.0), yüksek maliyet (\%22.0), ekili alan eksikliği (\%20.0); geleneksel işletmelerde ise yem bitkisi üretiminin olmamas1 (\%26.0), yetersiz ve uygun olmayan ahır (\%14.0), işgücü eksikliği (\%4.0), yüksek maliyet (\%26.0), ekili

\section{Sonuç ve Öneriler}

Bu çalışmada Mersin, Adana, Osmaniye, Hatay illerinde süt sığırcılığı yapan işletmelerin yapısal özelliklerini ortaya koymak ve mevcut sorunlara çözüm önerileri geliştirmek amaçlanmıştır. $\mathrm{Bu}$ amaçla yapılan anketlerden elde edilen sonuçlara göre üreticilerin büyük bir bölümü orta yaşl1, 19 yıllık süt sığırı yetiştiriciliği tecrübesine sahip, lise mezunu, aile bireylerinin büyük bir çoğunluğu işletmede çalışan, temel gelir kaynağı hayvansal üretim olan ve son beş yılda tarımsal yatırım yapan bireylerden oluşmaktadır. Bölgede kültür ırkı ineklerin bulunduğu küçük aile işletmeleri çoğunluktadır. Tarımda aile işletmeciliğinin sürdürülebilir olması aile bireylerinin tamamına yönelik eğitimlerin ve üretime ilişkin destekleme politikalarının iyileştirilmesi ile mümkün olacaktır.

İşletmelerin karlılığını artırmak ve sürdürülebilirliğini sağlamak için süt verimini artırıc1 misır silaj1 üretimi desteklenmeli, üreticilere silajlık mısır yetiştiriciliği ve silaj yapımı konularında eğitim verilmelidir. Bunun yanı sıra süt sığırcılığında önemli girdilerden olan yem bitkileri yetiştiriciliğinin; süt verim, kalite ve maliyet üzerine etkilerinden ve işletmelerinde yem bitkileri yetiştiriciliğinin öneminden bahsedilmelidir. Yem fiyatlarının yüksek olmasından memnun olmayan üreticilere karlı üretime imkan tanıması açısından yem bitkileri üretimi yapabilecekleri arazi tahsis edilmelidir.

Hayvan yetiştiriciliğinde sağlıklı sürü yönetiminin yapılabilmesi açısından, çobanların deneyimli olması büyük önem taşımaktadır. Bu nedenle süt sığırcılığ 1 işletmelerinde sertifikalı çoban bulundurulmasına imkan sağlayacak, yeterli sayıda sertifikalı çoban yetiştirilmesi için Tarım ve Orman Bakanlığı ile Milli Eğitim alan eksikliği (\%18.0) sorunlarının olduğunu belirlemişlerdir.

Bakır ve Kibar (2019), Muş ilinde süt sığırcılığ 1 işletmelerinde yemin pahalı (\%81.2) ve destek priminin az olmasindan (\%52.0) ayrica pazarlama olanaklarının, kredilerin ve kaba yem temininin yetersizliğinden üreticilerin memnun olmadıklarını belirlemişlerdir.

Bakanlığı ortak projeler yürütmelidir. Bakım ve beslenme konuları başta olmak üzere işletmede süt üretiminin (sağım ünitesi, soğutma tankları) teknolojik ve hijyen koşullarına uygun yapılabilmesi için işletmeye mali destek verilmesi gereklidir.

İşletme kayıtlarının tutulması; işletmelerin verimliliği ve karlılığının artması, sürdürülebilirliği sağlanma açısından büyük öneme sahiptir. İncelenen işletmelerde kayit defteri tutulmadığı saptanmıştır. Süt sı̆̆ırcılığ işletmelerinin tohumlama, doğum, sağlık, hayvanların ağırlıkları, sürüden çıkarılan hayvanlar gibi önemli konularda kayıt tutmalarını artırmak amaciyla bilgilendirme çalışmaları ve desteklemeler yapılabilir. Araştırma bölgesinde işletmeler hayvansal ürünleri firmalara pazarlamaktadır. Üreticilerin hayvansal ürünleri satış aşamasında önemli problemlerinin olduğu ve uzun zamandır çözüme kavuşmasını bekledikleri saptanmıştır.

Türkiye'de üretici örgütleri, kooperatiflerin desteklenmesi, kooperatifler aracılığıyla düşük girdi temini ve ürün alımının sağlanması için yeni tarım politikalarının oluşturulması birim hayvandan alınan süt miktarının artırılması, işletmelerin gelir ve refah seviyelerinin yükselmesinde büyük önem arz etmektedir.

\section{Kaynaklar}

Akman, N., Özkütük K., Kumlu S, Yener S.M. (2013). Türkiye'de Sı ̆̆ır Yetiştiriciliği ve Sığır Yetiştiriciliğinin Geleceği. ZMO, s:741-764.

Aksoy, A., Külekçi, M., Yavuz F. (2011). Analysis of The Factors Affecting The Adoption of Innovations in Dairy Farms in Erzurum Province, Turkey. African Journal of Agricultural Research, 6 (13): 2966-2970.

Anonim, (2021). Tarım Ürünleri Piyasaları 
Raporu,

https://arastirma.tarimorman.gov.tr/tepge/ Belgeler/PDF\%20Tar\%C4\%B1m\%20\%

C3\%9Cr\%C3\%BCnleri\%20Piyasalar\%C $4 \% \mathrm{~B} 1 / 2020-$

Temmuz\%20Tar\%C4\%B1m\%20\%C3\%9 Cr\%C3\%BCnleri\%20Raporu/S\%C3\%B

$\mathrm{Ct}, \% 20$ Temmuz-

2020,\%20Tar\%C $4 \% \mathrm{~B} 1 \mathrm{~m} \% 20 \% \mathrm{C} 3 \% 9 \mathrm{Cr}$

\%C3\%BCnleri\%20Piyasa\%20Raporu.pd

f (Erişim Tarihi: 31.03.2021)

Ata, N., Yilmaz, H. (2015). Türkiye'de Uygulanan Hayvansal Üretimi Destekleme Politikalarının Süt Siğırcılığ İsletmelerine Yansımaları: Burdur İli Örneği, SDÜ Ziraat Fakültesi Dergisi, 10(1): 44-54.

Bakır, G., Kibar, M., (2019). Muş İlinde Bulunan Süt Sığırcilığı İşletmelerinin Bazı Yapısal Özelliklerinin Crostabb Analiziyle Belirlenmesi, KSÜ Tarım ve Doğa Derg, 22(4): 609-619.

Boz, İ. (2013). Doğu Akdeniz Bölgesi'nde Süt Siğırcılığ1 Yapan İşletmelerin Yapısı, Sorunları ve Çözüm Önerileri, Kahramanmaraş Sütçü İmam Üniversitesi, KSÜ Doğa Bilimleri Dergisi, 16(1): 24-32.

Büyükcan, B., Tan, S. (2020). Çanakkale İli Biga İlçesinde Süt Üreticilerinin Hayvancılık Politikalarına Bakış Açılarının İncelenmesi, Atatürk Üniv. Ziraat Fak. Derg., 51 (3): 258-266.

Curabaz, A. (2009). Adana İlinde Büyükbaş Süt Hayvancılık İşletmelerinin İncelenmesi, Çukurova Üniversitesi, Fen Bilimleri Enstitüsü, Yüksek Lisans Tezi, Adana.

Dönmez, H. (2019). Süt Siğırcılığından Elde Edilen Ahır Gübresi Uygulamalarının Sürdürülebilir Tarım Açısından Değerlendirilmesi ve Ekonomik Analizi: Burdur İli Örneği, Isparta Uygulamalı Bilimler Üniversitesi Lisansüstü Eğitim Enstitüsü, Isparta.

FAO. (2013). Milk and dairy hold potential for improving nutrition of world's poorhttp://www.fao.org/ news/story/en/item/203977/icode/ (22.05.2021).

FAO. (2020). Food And Agricultural
Organization,

http://www.fao.org/home/en

FAO. (2021). Food And Agricultural Organization,

http://www.fao.org/home/en

Gençdal, F., Terin, M., Yıldırım, İ. (2015). Süt sığırcılığ yaptırma durumuna etki eden faktörlerin belirlenmesi üzerine bir araştırma: Van ili Gevaş ilçesi Örneği, Anadolu Tarım Bilim. Derg./Anadolu J Agr Sci, 30 (2015) 254-259.

Gönç, S., Oysun, G., Kınık, Ö., Uysal, H.R. (1993). Endotoksinin İçme Sütlerinin Kalitelerinin Tespitinde İndikatör Olarak Belirlenmesi Üzerine Bir Araştırma, TUBITAK, Proje No: TBGAG 26.

Güğercin, Ö., Baytorun, N., Koç, D.L., Polat, B., Büyüktaş, K., Polat, Ö.D. (2017). Adana Îlinde Bulunan Bazı Süt Sığırcılığı İşletmelerindeki Hayvan Barınaklarının Mevcut Durumlarının Belirlenmesi, Çukurova Tarım Gıda Bilimleri Dergisi, 32: 19-28.

Gülsün, B., Miç, P. (2018). Rasyon Hazırlamada Temel Yem Miktarlarının Ekonomik Olarak Belirlenmesi İçin Çok Amaçlı Programlama Yaklaşımı, Ömer Halis Demir Üniversitesi Mühendislik Bilimleri Dergisi, 7(2): 634-648.

Günhan, T., Demir, V., Bilgen, H. (2006). Çiftlik Tipi Süt Soğutma Tanklarının Performans Değerlerinin Deneysel Olarak Belirlenmesi, Ege Üniversitesi Ziraat Fakültesi Tarım Makinaları Bilimi Dergisi, 2(4): 369-379.

Gürgen, Y. (2005). Mastitis (Meme İltihab1), Çukurova Üniversitesi, Tarımsal Yayım ve Haberleşme Araştırma ve Uygulama Merkezi, Çiftçi Broşürü, Adana.

Karakuş, S. (2021). Afyonkarahisar İli'nde Ipard Kapsaminda Kurulan Süt Siğirciliği İşletmelerinin Teknik Ve Ekonomik Performans1, Afyon Kocatepe Üniversitesi, Sağlık Bilimleri Enstitüsü, Yüksek Lisans Tezi, Afyonkarahisar.

Maç, H., Yilmaz, H. (2016). Analysis of factors related with farmers' benefiting from forage crops production support: Evidence from a survey for the Central 
Anatolia Region of Turkey. Revista De La Facultad De Agronomia De La Universidad Del Zulia (LUZ) 33: 232254.

Newbold, P. (1995). Statistics for Business and Economics. Prentice-Hall International, New Jersey.

Ozyakar D.H., Y1lmaz, H. (2021). Süt Sığırcıllı̆ı İşletmelerinde Ahır Gübresi Kullanımının ve Yönetiminin Ekonomik Analizi: Burdur İli Örneği, Türk Tarım Gıda Bilim ve Teknoloji Dergisi, 9(3): 460-469.

Saral, A., Vatandaş, M., Güner, M., Ceylan M., Yenice, T. (2000). Türkiye Tarımının Makinalaşma Durumu, TMMOB Ziraat Mühendisleri Odas1, V. Teknik Kongresi, S. 901-923, Ankara.

Sayar, S. (2018). Süt Sığırcılığı İşletmelerinde Kadınların İşgücüne Katılımının Analizi: Erzurum İli Pasinler İlçesi Örneği, Atatürk Üniversitesi, Fen Bilimleri Enstitüsü, Yüksek Lisans Tezi, Erzurum.

Semerci, A., Çelik, A.D. (2017). Süt Sı ̆̆ırcılı̆̆ı İsletmelerinde Sermaye Yapısı: Hatay İli Örneği, Gaziosmanpaşa Üniversitesi Ziraat Fakültesi Dergisi, 34(3): 201-209.

Semerci, A., Parlakay, O., Çelik, A.D. (2014). Hatay İlinde Süt Üretiminin Ekonometrik Analizi, XI. Ulusal Tarım Ekonomisi Kongresi 3-5 Eylül 2014, Samsun.

Şahin, K., Gül, A., Koç, B., Dağıstan, E. (2001). Adana İlinde Entansif Süt Sığırc1lığı Üretim Ekonomisi, Yüzüncü Y1l Üniversitesi, Ziraat Fakültesi, Tarım Bilimleri Dergisi,11 (2): 19-28.

Şeker, İ., Tasalı, H., Güler, H. (2012). Muş İlinde Sığır Yetiștiriciliği Yapılan İşletmelerin Özellikleri, Frrat Üniversitesi Sağlık Bilimleri Veteriner Dergisi, 26(1):09-16.

TİGEM. (2019). Hayvancılik Sektör Raporu,Tarım İşletmeleri Genel Müdürlüğü.

https://www.tigem.gov.tr/WebUserFile/D osyaGaleri/2018/2/a374cc25-acc1-44e8a54663b4c8bce146/dosya/2019\%20YILI \%20HAYVANCILIK\%20SEKTOR\%20 RAPORU.pdf (Erişim Tarihi: 31.03.2021)
Turan, Z., Şanver, D., Öztürk, K. (2017). Türkiye'de Hayvancılık Sektöründen Süt İnekçiliğinin Önemi ve Yurt İçi Hasılaya Katkisi ve de Diş Ülkelerle Karşılaştırılması, Ömer Halisdemir Üniversitesi İktisadi ve İdari Bilimler Fakültesi Dergisi, 10(3): 60-74.

Tutkun, M., Denli, M. ve Sessiz, A. (2017). Diyarbakır İli Süt Siğırcılığ İşletmelerinin Yapısal Durum Analizi, Türk Tarım - Gıda Bilim ve Teknoloji Dergisi, 5(5): 476-483.

Yilmaz, H., Ata, N. (2016). Assessing The Impact of Dairy Policies on the Socioeconomic and Technological Characterization of Turkish Dairy Industry, AgroLife Scientific Journal, 5 (1): 214-222.

Yılmaz, H., Ayasan, T., Sağlam, C., Gül, M. (2020). Socio-Economic Characteristics of Dairy Farms and Use Level of Feedstuff in the Eastern Mediterranean Region, Turkish Journal of Agriculture Food Science and Technology, 8(1): 8994.

Yılmaz, İ., Dağıstan, E., Koç, B., Özel, R. (2003). Hatay İlinde Projeli Ve Projesiz Süt Sığırcılığ 1 Yapan İşletmelerin Süt Sığırcılığı Üretim Faaliyetlerinin ve faktör Verimliliklerinin Analizi, Akdeniz Üniversitesi Ziraat Fakültesi Dergisi, 16(2): 169-178.

ZMO. (2019). Süt Raporu 2018, https://www.zmo.org.tr/resimler/ekler/62 a096b3a91b26b_ek.pdf?tipi=38\&turu=D $\&$ - sube $=0(27.05 .2021)$ 
Süt Sığırcılığı İşletmelerinin Yapısal Özellikleri 